\title{
Diagnostic accuracy of serum enzyme assays for myocardial infarction in a general hospital population
}

\author{
-David M. Goldberg and David A. Winfield \\ From the Department of Chemical Pathology, The Royal Hospital, Sheffield $S_{I}{ }_{3} S R$
}

-An analysis was made of the final diagnosis and results of sequential serum enzyme determinations in 2709 cases of suspected myocardial infarction. The material was classified into patients in whom the diagnosis was established by clinical and electrocardiographic criteria (807); those in whom the diagnosis was established by clinical criteria alone (140), or by electrocardiographic criteria only (85); and patients in whom the diagnosis was rejected on clinical and cardiographic findings (1553); the remainder (124) could not be classified.

Serum creatine: ATP phosphotransferase (CPK) was raised more frequently in positive cases and less frequently in negative cases than the other enzymes assayed, and the extent of increase in the former was much the highest relative to the upper normal limit for that enzyme. Serum $\alpha$-hydroxybutyrate dehydrogenase (HBD) activity showed more modest increases in positive cases, "and was raised at some point during investigation in 15 per cent of negative cases, but was especially valuable in confirming the diagnosis in patients presenting more than 72 hours after onset of symptoms. Aspartate aminotransferase activity of serum was difficult to interpret unless alanine - aminotransferase activity was also known; even then the information did not always justify the effort of making these estimations routinely additional to those of serum CPK and HBD activities.

"The raised levels of serum enzymes in man subsequent to acute myocardial infarction have been well documented. Those most commonly used in routine diagnosis at the present time include aspartate aminotransfertase (LaDue, Wroblewski, and Karmen, 1954), creatine:ATP phosphotransferase (Dreyfus et al., 1960), and the fast cationic fractions of lactate dehydrogenase characterized by their ability to catalyse the reduction of 2oxobutyrate and designated ' $\alpha$-hydroxybutyrate dehydrogenase activity' (Rosalki and -Wilkinson, 1960; Elliott and Wilkinson, I96I; Konttinen and Halonen, 1962).

Comparative assessments of these enzymes as diagnostic tests have been made from time - to time (see Table 3), but most of these reports have been based on cases restricted in number and variety, and several describe the experience of specialized cardiology units where preselection of the clinical material is bound to influence the conclusions reached. The present analysis of a large and unselected group of patients submitted for routine

Received I3 August 1971. laboratory diagnosis is intended to provide a more realistic assessment of the merits and limitations of these tests in assisting the diagnosis of myocardial infarction in a general hospital population.

\section{Materials and methods}

All samples submitted to this laboratory for determination of serum enzymes in cases where a diagnosis of myocardial infarction was suspected were analysed in respect of the period from I June I968 to 3I August I970. The patients were drawn from all hospitals within the United Sheffield Hospitals Group, and some were referred from general practices and peripheral hospitals in the vicinity. The determinations were carried out by the following techniques: aspartate aminotransferase (GOT) and alanine aminotransferase (GPT) by semiautomated kinetic procedures giving normal ranges of 5-40 and 5-30 International Units per litre (IU/1.) respectively at $37^{\circ} \mathrm{C}$ (Ellis and Goldberg, 1970); creatine:ATP phosphotransferase (CPK) by a colorimetric assay with normal range $15-70 \mathrm{IU} / 1$. at $37^{\circ} \mathrm{C}$ (Worthy, Whitehead, and Goldberg, 1970); and $\alpha$-hydroxybutyrate dehydrogenase (HBD) by a fully automated procedure utilizing absorbance change at 
$340 \mathrm{~nm}$ and yielding a normal range of $30-200$ IU/1. at $25^{\circ} \mathrm{C}$ (Hirst and Goldberg, I970). On the basis of the details on the laboratory request form, patients were placed by us in a "cardiac investigation stream' and the following protocol was observed: on the first sample, which medical staff were encouraged to take at the earliest possible opportunity even if this lay outside normal laboratory hours, all 4 enzyme determinations were carried out and a request sent to the ward or the practitioner for a second specimen exactly 24 hours after the first. On the second sample, all determinations except GPT activity were carried out as a routine; GPT activity was determined only if the aminotransferase ratio of the initial sample raised the possibility of hepatic involvement, i.e. GPT:GOT>I.0. A third sample was routinely sought 24 hours after the second and HBD activity determined; if the results of the earlier samples were inconsistent or in conflict with the diagnosis, all 4 enzymes were assayed, and if necessary further samples requested or the assays on the earlier samples repeated.

One to two weeks later, the medical staff were contacted with a view to classifying the patient into one of the following 4 categories, and in doing so they were asked not to take account of the enzyme results.

I) Positive To qualify for this group, serial electrocardiographic examinations on the patient had to provide convincing evidence of myocardial infarction; and clinical support in the form of characteristic pain, shock, hypotension, and increase in temperature, white cell count, and ESR was required.

2) Clinically positive Patients in this category had all the clinical features present in the above group, and these features could not be explained on grounds other than myocardial infarction despite careful investigation. But serial electrocardiograms yielded negative or equivocal conclusions, often because of abnormalities persisting from previous episodes of myocardial infarction.

3) Electrocardiogram positive Patients in this category presented unequivocal evidence of recent myocardial infarction on electrocardiographic examination, but the clinical features of infarction were lacking. Pain was neither characteristic of infarction nor prominent among the patient's complaints, and in many cases the diagnosis was reached in the course of investigating unexplained cardiac failure, arrhythmia, hypotension, or embolism. In many cases within this group, the precise time of myocardial infarction could not be ascertained.

4) Negative The clinical features in these patients were rarely pathognomonic of infarction though the latter condition had to be considered in the differential diagnosis. In most cases a final diagnosis other than that of myocardial infarction provided an adequate basis for the clinical picture, and the electrocardiograms gave normal or equivocal results.
Cases placed by the medical staff in the first category, in which raised levels of CPK, HBD, and GOT were obtained in at least one specimen, and where GPT activity was normal or only slightly raised, were accepted as correctly diagnosed. Cases placed in the fourth category, in which enzyme tests were consistently normal, or where an isolated rise in GPT was the only abnormality, were likewise accepted as correctly diagnosed. All other cases in these two categories, as well as all cases in the second and third categories, were checked by us retrospectively to ensure that the diagnosis was correct and to ascertain a possible reason for the anomalous enzyme results. Approximately 850 case records were checked in this way and about I in Io had to be reclassified because of obvious errors in the information originally provided to us. Special attention was given to estimating the time of onset of symptoms in the positive cases. The assessment of the medical staff on this point was accepted after detailed discussion, though here too the information was subsequently checked in the case records if it conflicted with the enzyme results.

\section{Results}

Positive cases A total of 807 cases fell into this category of which 750 had at least one blood sample drawn between 12 and 72 hours after onset of symptoms. The distribution of results for the enzyme determinations based upon the highest value for each is shown, in respect of these 750 cases (Fig. I). CPK activity was the most sensitive index of response to infarction in that 46 per cent of the cases had on at least one occasion a value more than seven times the upper normal limit, and only 7 per cent failed to show raised activity in any sample. With GOT, 21 per cent of the cases had a value greater than 7.5 times the upper normal limit, and 7 per cent failed to show raised activity in any sample, but 5 per cent of cases with raised GOT had even higher values for GPT in the same sample and were thus classified as having equivocal aminotransferase results. HBD was least sensitive, only 37 per cent of the cases yielding values more than 2.5 times the upper normal limit, and in 9 per cent all values were normal.

All three enzymes were normal in 3 per cent of the cases (Table 1 ) and all three were raised in 82 per cent; this latter figure rose to 85 per cent, if cases with high GPT activity were included. Table I also presents an analysis of 43 cases where the earliest sample was taken later than $\mathbf{7 2}$ hours after onset of symptoms, and 14 cases in which the first sample was taken within 12 hours of onset and no subsequent sample was obtained, due to the demise of the patient. The value of HBD and 

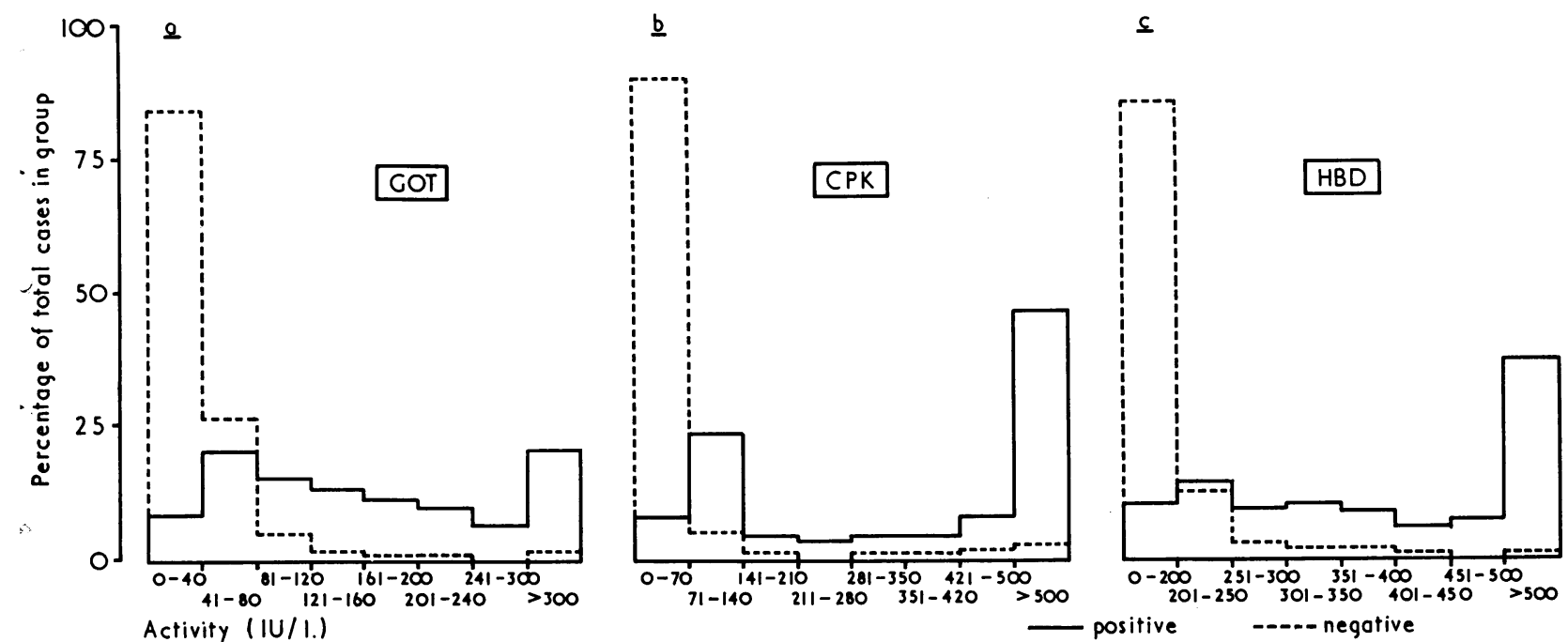

FIG. I Percentage distribution of enzyme activities (IU/l.) in all patients finally classified as positive (807 cases) and negative (1553 cases) for myocardial infarction by clinical and electrocardiographic criteria.

the lack of value of CPK in assisting the diagnosis of infarction in those patients presenting 'several days after the clinical event is obvious. GOT seemed the most useful enzyme test in confirming the diagnosis where presentation - was early.

Clinically positive One hundred and forty cases were placed in this category. The distribution of enzyme activities is presented in Fig. 2 and the results are analysed in Table $I$. All enzymes were normal in 29 of these cases, and all three raised in 48 , though in a further 3 cases high GPT activity accompanied the raised GOT, CPK, and $\mathrm{HBD}$. As with the previous category, CPK seemed to be the most sensitive test for confirming suspected infarction. Of these 140 cases, 6 were examined for the first time more than 72 hours after the onset of symptoms; 2 of these 6 had raised HBD activities and no other abnormalities were present. Exclusion of these cases obviously improved the overall incidence of abnormal findings in this category.

Electrocardiogram positive Eighty-five cases were placed in this category: the analysis of the results is given in Table $\mathrm{I}$, and the dis-

TABLE I Abnormalities found in patients submitted for serum enzyme investigations to confirm or exclude diagnosis of myocardial infarction based on highest value obtained on serial examinations: percentages in parentheses

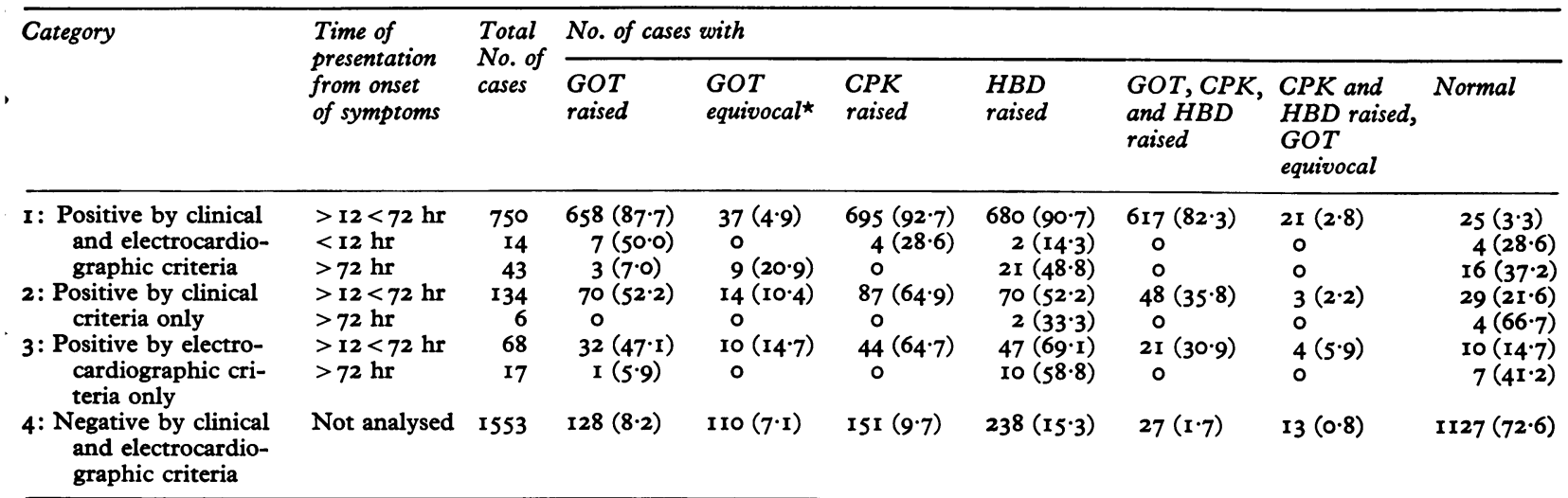

* Refers to cases in whom both aminotransferases were raised, but GPT $>$ GOT. 

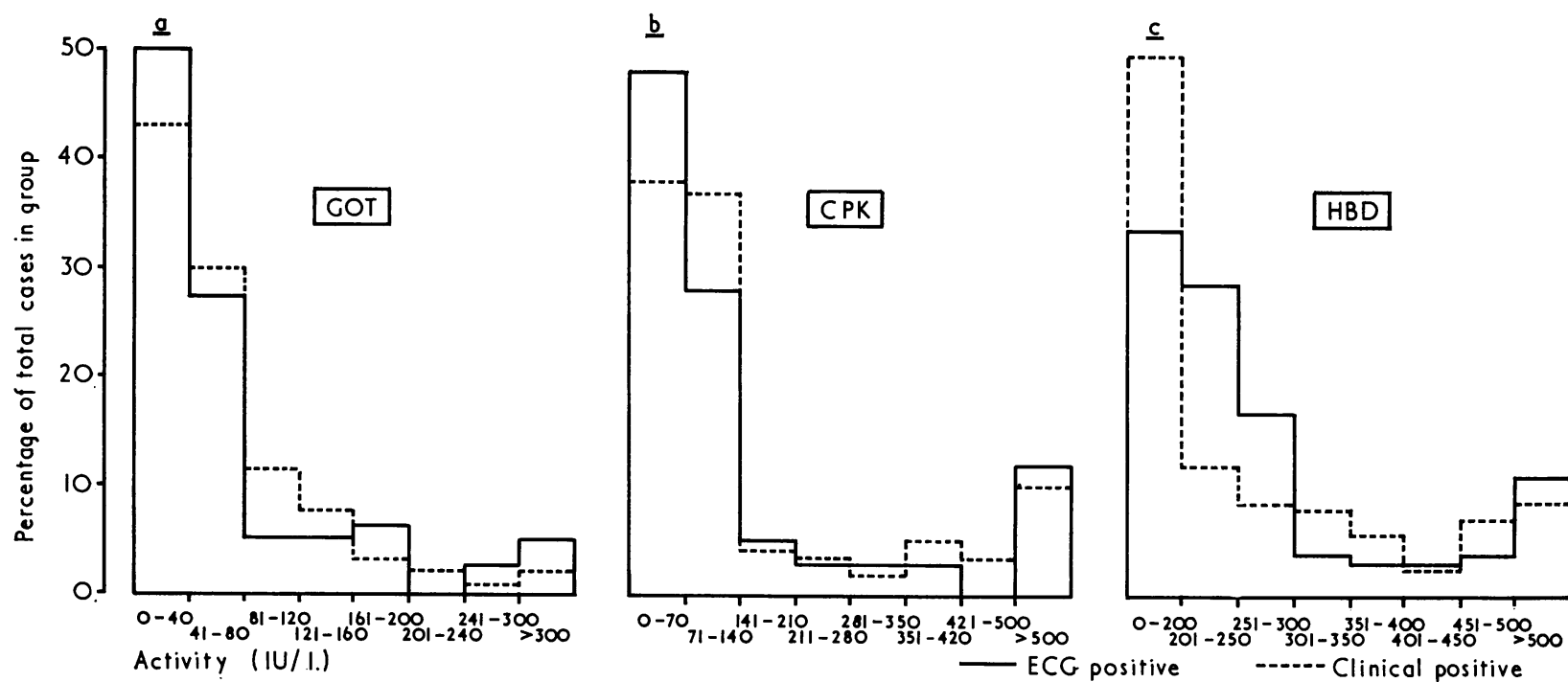

FIG. 2 Percentage distribution of enzyme activities (IU/l.) in all patients in whom myocardial infarction was diagnosed by electrocardiographic criteria alone ( 85 cases) and by clinical criteria alone ( 140 cases).

tribution of enzyme activities in Fig. 2. The greatest incidence of abnormal values was given by HBD, though CPK increases approached this high incidence when 17 cases presenting more than 72 hours after the suspected episode of infarction were excluded. These 17 included Io patients with raised HBD activity, emphasizing once more the value of this determination in the late case. GOT elevation was encountered in only 33 cases in this category, though a further ro cases had high GPT levels accompanying raised GOT activity.

Negative The cases placed in this category numbered 1553: the analysis of the enzyme results is presented in Table $I$ and their distribution in Fig. I. In 73 per cent of these cases, all enzyme determinations were consistently normal. Two hundred and thirtyeight cases yielded abnormal values for HBD in at least one sample. An equal number of patients gave at least one raised value for GOT, though in I Io of these subjects GPT activity was even higher in the same specimen. The smallest number of abnormal values (I5I) occurred with CPK.

The final diagnosis in those subjects in this category showing an abnormality of any of the three enzymes is shown in Table 2. Lung disease was a common cause of raised values for all three enzymes. Congestive cardiac failure also figures prominently, especially in association with raised HBD activity.
Surgical operations and cerebrovascular accidents were associated predominantly with raised CPK activity, but the incidence of raised GOT and HBD in these conditions was far from negligible. Pulmonary embolism is listed as a separate entity, HBD elevation being mainly implicated. In many cases, the cause of a raised HBD activity was ascribed to haemolysis of the sample, and in a few, where a second episode was suspected but disproved, to persisting rises from an episode of infarction within the previous two weeks; a few subjects with raised HBD activity were found to be uraemic. The diagnosis in cases grouped as 'other diseases' included cancer, leukaemia, and renal disease without uraemia.

Unclassified One hundred and twenty-four cases could not be classified. In the main, these were patients with equivocal electrocardiographic patterns and conflicting clinical features which only partly fulfilled the criteria for inclusion in the second category, and which could not be fitted into a clear-cut alternative diagnosis. The data on these subjects were not analysed.

\section{Discussion}

The data in this report extend observations recorded for the first 6-month period covered by this investigation (Goldberg, I97I). The conclusion then reached was that great caution was needed in interpreting enzyme chan- 
ges in the differential diagnosis of myocardial infarction, since consistently normal values were found in a proportion of proven cases, and consistently raised values in certain patients known not to have suffered infarction. This conclusion remains valid, though the percentage of false-positive and false-negative results is less than that apparent from the earlier analysis. Though the assay techniques have not changed, improved proficiency in their operation and better laboratory quality control have made a contribution. Greater familiarity with the system on the part of medical staff has resulted in better accuracy in the timing of samples, more free exchange of information between ward and laboratory, and speedier awareness on both sides of possible analytical errors which could be checked before deterioration of the sample. It is nevertheless probable that a proportion of anomalous results stems from unrecognized laboratory errors, or mistakes in sample identification in wards and clinics or during separation and transit from peripheral laboratories in the group to the central laboratory.

Early reports and reviews created the im-pression that abnormal GOT levels were almost invariably obtained between 12 and 72 hours after myocardial infarction (Chinsky, Shmagranoff, and Sherry, 1956; Chinsky, Wolff, and Sherry, 1957; Wroblewski, 1958; Agress, 1959). Subsequent authors have observed GOT rises less consistently after myocardial infarction, incidences ranging from 80 to 95 per cent being more usual (Table 3). By the same token, the incidence of raised CPK and HBD activities subsequent to myocardial infarction ranges from 90 to Ioo per cent in the series reported by various authors (Table 3). It is interesting that the experience of those authors who have reported more than one series is not always consistent, emphasizing the influence of case material, numbers, and diagnostic criteria upon the conclusions reached. The present results, together with those cited in Table 3, indicate that enzyme values that are consistently normal, even when samples are obtained between 12 and 72 hours after onset of symptoms, are not in themselves sufficient grounds for discarding a diagnosis of myocardial infarction.

It is equally clear that increases in activity of GOT, CPK, and HBD, even when these occur in the same sample within 72 hours of a clinically significant event, do not constitute a diagnosis of myocardial infarction unless other possible causes have been excluded. The 27 cases in which all three enzymes were raised and GPT was normal were distributed as follows: lung disease (6), cerebrovascular
TABLE 2 Final diagnosis in cases negative by clinical and electrocardiographic criteria (fourth category) showing raised enzyme values in at least one sample during investigation

\begin{tabular}{|c|c|c|c|c|}
\hline \multirow[t]{2}{*}{ Diagnosis } & \multicolumn{4}{|c|}{ No. of cases } \\
\hline & $\begin{array}{l}G O T \\
\text { raised }\end{array}$ & $\begin{array}{l}\text { GOT } T^{\star} \\
\text { equivocal }\end{array}$ & $\begin{array}{l}C P K \\
\text { raised }\end{array}$ & $\begin{array}{l}H B D \\
\text { raised }\end{array}$ \\
\hline Lung disease $\nmid$ & 22 & 17 & 26 & 29 \\
\hline Congestive cardiac failure & 20 & 24 & 12 & 40 \\
\hline Pulmonary embolus & 5 & 13 & 8 & 18 \\
\hline Cardiac ischaemia & 7 & 2 & 7 & 15 \\
\hline Cardiac arrhythmia & 3 & 8 & 8 & 13 \\
\hline Pericarditis & 4 & - & 5 & 6 \\
\hline Raised from previous episode & 工 & - & 二 & 4 \\
\hline Postoperation & 20 & I I & 28 & 16 \\
\hline Hepatobiliary disease & 2 & $2 I$ & 3 & 9 \\
\hline Cerebrovascular accidents & 16 & 2 & 20 & 15 \\
\hline Epilepsy & 7 & 2 & 7 & 3 \\
\hline Drug overdose & 7 & $\mathbf{I}$ & 7 & 2 \\
\hline Diabetic coma & - & $\mathbf{I}$ & 2 & 2 \\
\hline Hypothyroid coma & 2 & - & 3 & 2 \\
\hline Uraemia & - & 3 & $\mathbf{I}$ & 12 \\
\hline Haemolysis of sample & 2 & - & 一 & 30 \\
\hline Megaloblastic anaemia & - & 一 & 一 & 8 \\
\hline Bacteraemic shock & 3 & $\mathbf{I}$ & 3 & 3 \\
\hline Others $\ddagger$ & 8 & 4 & II & $\mathbf{I}$ \\
\hline Total & 128 & IIO & ISI & 238 \\
\hline
\end{tabular}

* Refers to cases in which both aminotransferases were raised, but GPT $>$ GOT. $\dagger$ Includes asthma and status asthmaticus, chronic bronchitis, and emphysema without heart failure, broncho- and lobar pneumonia, and pulmonary tuberculosis. $\ddagger$ Includes cancer, leukaemia, and renal disease without uraemia.

accident (5), severe pyrexia associated with bacteraemic shock (3), pericarditis (3), major operation (3), cardiac arrhythmia (2), drug overdose (2), myxoedema with coma (I), pulmonary embolism (I), and epilepsy (I). In most of these conditions, enzyme tests will be of value only in so far as consistently normal results will help to exclude myocardial infarction.

The detailed analysis of those cases in the fourth category in which raised enzyme activities were found (Table 2) provides further information for assessing the limitations of the individual tests, and the distribution of these abnormalities in different diseases conforms broadly to the experience of those authors cited in Table 3. In particular, the lack of specificity of increases in GOT has been well recognized (Wroblewski, 1958, 1959). This makes it imperative to have simultaneous measurement of GPT activity; if this exceeds GOT activity, it points to the presence of an intra-abdominal lesion or hepatic involvement as the likely explanation for the raised GOT, and as shown in Table 2 helps to eliminate many of the false-positive results for GOT that might otherwise be accepted. On the other hand, the injudicious application of this principle would also require the setting aside 
of a proportion of high GOT results from positive cases, as shown in Table $I$.

The uncertainty in interpretation to which aminotransferase determinations are prone prompted the development of alternative tests, but these are not without snags which must be clearly appreciated by those intending to use them. Raised HBD values are often encountered in liver disease, muscle disease, heart failure, and megaloblastic anaemia (Pagliaro and Notarbartolo, 1962; Rosalki, 1963; Elliott and Wilkinson, 1963; Johnston et al., 1966), and a recent study showed a high proportion of abnormal results in pulmonary embolism (Coodley, 1969). Haemolysis of the sample has long been recognized as a troublesome source of false-positive HBD increase. To the extent that any routine laboratory inevitably receives a proportion of such samples, the value of this test is thereby diminished. Though intra-abdominal disease was associated infrequently with rises in CPK in this series, raised values have been reported in alcoholic intoxication (Nygren, 1966), chronic liver disease (Eshchar and Zimmerman, 1967), and acute pancreatitis (Rinderknecht et al., 1970). In addition to welldocumented conditions such as trauma and operations, cerebral infarction, infective lung disease, physical exercise, and hypothyroidism (Graig and Ross, 1963; Hess et al., 1964; Velez-Garcia et al., 1966; Savignano, Hanok, and Kuo, 1969), raised levels of CPK have been reported in acute psychosis (Meltzer, I968), in subarachnoid haemorrhage (Hunt, McRae, and Zapf, 1969), and in less severe forms of cerebral dysfunction (Schiavone and Kaldor, 1965), after anaesthesia for ophthalmic operations (Tammisto and Airaksinen, 1966), and after hypothermia or barbiturate overdosage (Maclean, Griffiths, and EmslieSmith, 1968). Since intramuscular injections may cause quite high rises in CPK activity (Hess et al., 1964, 1967; Batsakis et al., 1968; Meltzer, Mrozak, and Boyer, 1970), it is difficult to estimate the influence of this factor upon the present results or those already published. The sensitivity of CPK to injection is clearly a disadvantage in its employment for diagnostic purposes. Despite this, and the variety of conditions in which increases may be encountered, it emerged as the enzyme test most frequently normal in the fourth category as well as the test most frequently abnormal in the first.

For these reasons, determination of CPK activity is the most reliable single test for the routine diagnosis of myocardial infarction. HBD is clearly of great value in the diagnosis of those cases presenting later than 72 hours
TABLE 3 Analysis of some representative reports describing enzyme changes after myocardial infarction corrected in so far as possible to exclude cases presenting $<12$ and $>72$ hours after onset of symptoms

\begin{tabular}{|c|c|c|c|c|}
\hline \multirow[t]{2}{*}{ Authors } & \multirow{2}{*}{$\begin{array}{l}\text { Total } \\
\text { No. of } \\
\text { cases }\end{array}$} & \multicolumn{3}{|c|}{$\begin{array}{l}\text { Percentage with raised } \\
\text { enzyme values }\end{array}$} \\
\hline & & $G O T$ & $C P K$ & $H B D$ \\
\hline Elliott, Jepson, and Wilkinson (1962) & 60 & 87 & - & 100 \\
\hline Pagliaro and Notarbartolo (1962) & I6 & 70 & - & 100 \\
\hline Sorensen (1963) & 52 & 98 & 100 & - \\
\hline Rosalki (1963) & 70 & 100 & - & 100 \\
\hline Rosalki and Wilkinson (1964) & 330 & 78 & 一 & 100 \\
\hline Preston, Batsakis, and Briere (1964) & 38 & - & - & 97 \\
\hline Hess et al. (1964) & 42 & $\star$ & $9 \mathrm{r}$ & - \\
\hline Smith (1964) & 50 & 92 & root & 92 \\
\hline Vincent and Rapaport (1965) & 40 & 100 & 100 & - \\
\hline Duma and Siegel (1965) & Io & 100 & 100 & - \\
\hline Stuart et al. (1965) & 100 & 87 & - & 100 \\
\hline Nissen, Ranløv, and Weis-Fogh (1965) & 55 & 98 & 89 & 96 \\
\hline Preston et al. (1965) & 15 & - & 100 & - \\
\hline Warburton, Bernstein, and Wright (1965) & 20 & 100 & 100 & 100 \\
\hline Griffiths (1966) & 68 & 87 & 96 & 94 \\
\hline Coodley (I966) & 28 & 86 & 92 & 93 \\
\hline Amador, Franey, and Massod (1966) & 62 & 100‡ & - & - \\
\hline Lewis (1967) & 43 & 98 & 98 & - \\
\hline Smith (1967) & 190 & 97 & 100 & 94 \\
\hline Eshchar and Zimmerman (1967) & $2 \mathbf{I}$ & 72 & 91 & - \\
\hline Hess et al. (1967) & 20 & - & 100 & - \\
\hline Dietz, Hodges, and Foxworthy (1967) & II & 91 & - & 91 \\
\hline Crowley (1967) & 373 & 94 & - & - \\
\hline Crowley (I968) & I2I & 93 & 83 & - \\
\hline Present & 750 & $92 \cdot 6 \S$ & $92 \cdot 7$ & $90 \cdot 7$ \\
\hline
\end{tabular}

* Stated to be less often raised than CPK but exact data not given. $\uparrow$ Based on 21 cases.

$\ddagger$ Only $76 \%$ raised when enzyme measured by alternative method. Includes cases classified in Table I as 'equivocal'.

after the onset of symptoms. This value is diminished somewhat by the high incidence of abnormal results in patients known not to have sustained myocardial infarction; but it must be emphasized that the normal ranges for these enzymes embrace only 95 per cent of the normal population, so that 2.5 per cent of normal subjects would be expected to exceed the upper limit. The data compiled in Table 2 therefore indicate those conditions most frequently associated with raised enzyme levels without implying that these conditions are responsible for the increases. Moreover, the protocol followed in the routine investigation of these patients was such that HBD was estimated much more frequently than the other enzymes, and therefore spurious increases due to chance or to technical factors are likely to have been greater. Even when both aminotransferases are determined, their diagnostic accuracy in myocardial infarction leaves much to be desired. In our opinion, their continued use is based more on custom, 
on their general availability, and on the comfort to be derived from a 'battery' of results all pointing in the same direction, rather than to any unique property they possess in this difficult clinical situation.

We are grateful to our clinical colleagues who provided the material and the information on which this report is based, and to the laboratory staff, in particular Mrs. I. M. Hoyland, A.I.M.L.T., who carried out the enzyme assays. Drs. E. Worthy and P. Whitehead, and Messrs. A. D. Hirst and G. Ellis collaborated in developing the methods used, and Professor Arthur Jordan was most helpful in organizing their routine operation.

\section{References}

Agress, C. M. (1959). Evaluation of the transaminase test. American fournal of Cardiology, 3, 74.

Amador, E., Franey, R. J., and Massod, M. F. (1966). Serum glutamic-oxaloacetic transaminase activity. Diagnostic accuracy of the revised spectrophotometric and the dinitrophenylhydrazine methods. Clinical Chemistry, 12, 475.

Batsakis, J. G., Preston, J. A., Briere, R. O., and Giesen, P. C. (1968). Iatrogenic aberrations of serum enzyme activity. Clinical Biochemistry, 2, 125.

Chinsky, M., Shmagranoff, G. L., and Sherry, S. (I956). Serum transaminase activity. Observations in a large group of patients. Fournal of Laboratory and Clinical Medicine, 47, 108.

Chinsky, M., Wolff, R. J., and Sherry, S. (1957). Serum transaminase activity: a comparison of the pyruvic and oxalacetic transaminases. American Fournal of the Medical Sciences, 233, 400.

Coodley, E. L. (1966). Current status of enzyme diagnosis in cardiovascular disease. American fournal of the Medical Sciences, 252, 633.

Coodley, E. L. (1969). Enzyme profiles in the evaluation of pulmonary infarction. Fournal of the American Medical Association, 207, 1307.

Crowley, L. V. (1967). The Reitman-Frankel colorimetric transaminase procedure in suspected myocardial infarction. Clinical Chemistry, 13, 482.

Crowley, L. V. (1968). Creatine phosphokinase activity in myocardial infarction, heart failure, and following various diagnostic and therapeutic procedures. Clinical Chemistry, 14, 1185.

Dietz, A. A., Hodges, L. K., and Foxworthy, D. T. (1967). Correlation of serum and urine enzyme activity in patients with acute myocardial infarction. Clinical Chemistry, 13, 359.

Dreyfus, J. C. Schapira, G., Resnais, J., and Scebat, L. (1960). La créatine-kinase sérique dans le diagnostic de l'infarctus myocardique. Revue française d'Études Cliniques et Biologiques, 5, 386.

Duma, R. J., and Siegel, A. L. (I965). Serum creatinine phosphokinase in acute myocardial infarction. Archives of Internal Medicine, I15, 443.

Elliott, B. A., Jepson, E. M., and Wilkinson, J. H. (1962). Serum $\alpha$-hydroxybutyrate dehydrogenase a new test with improved specificity for myocardial lesions. Clinical Science, 23, 305.

Elliott, B. A., and Wilkinson, J. H. (196r). Serum ' $\alpha$-hydroxybutyric dehydrogenase' in myocardial infarction and in liver disease. Lancet, $1,698$.

Elliott, B. A., and Wilkinson, J. H. (1963). The serum
' $\alpha$-hydroxybutyrate dehydrogenase' in diseases other than myocardial infarction. Clinical Science, $24,343$.

Ellis, G., and Goldberg, D. M. (1970). Use of the SP 800 spectrophotometer with work simplification in routine aminotransferase determinations. Spectrovision, $23,8$.

Eshchar, J., and Zimmerman, H. J. (1967). Creatine phosphokinase in disease. American fournal of the Medical Sciences, 253, 272.

Goldberg, D. M. (I97I). Enzymes in the diagnosis of myocardial infarction and liver disease. Annals of Clinical Biochemistry, 8, 195.

Graig, F. A., and Ross, G. (1963). Serum creatinephosphokinase in thyroid disease. Metabolism: Clinical and Experimental, 12, 57.

Griffiths, P. D. (1966). ATP: creatine phosphotransferase in the diagnosis of acute chest pain. British Heart fournal, 28, 199.

Hess, J. W., MacDonald, R. P., Frederick, R. J., Jones, R. N., Neely, J., and Gross, D. (1964). Serum creatine phosphokinase (CPK) activity in disorders of heart and skeletal muscle. Annals of Internal Medicine, 61, ror 5.

Hess, J. W., MacDonald, R. P., Natho, G. J. W., and Murdock, K. J. (1967). Serum creatine phosphokinase: evaluation of a commercial spectrophotometric method. Clinical Chemistry, 13, 994.

Hirst, A. D., and Goldberg, D. M. (1970). Application of new ultra-micro automated spectrophotometric determination for serum hydroxybutyrate dehydrogenase activity to diagnosis of myocardial infarction. British Heart Fournal, 32, I 14.

Hunt, D., McRae, C., and Zapf, P. (1969). Electrocardiographic and serum enzyme changes in subarachnoid hemorrhage. American Heart fournal, 77, 479.

Johnston, H. A., Wilkinson, J. H., Withycombe, W. A. and Raymond, S. (1966). Alpha-hydroxybutyrate dehydrogenase activity in sex-linked muscular dystrophy. Fournal of Clinical Pathology, 19, 250.

Konttinen, A., and Halonen, P. I. (I962). Serum $\alpha-$ hydroxybutyric dehydrogenase (HBD) in myocardial infarction. Comparison with glutamic oxalacetic transaminase (GOT) and lactic dehydrogenase (LDH). American fournal of Cardiology, 10, 525.

LaDue, J. S., Wroblewski, F., and Karmen, A. (1954) Serum glutamic oxaloacetic transaminase activity in human acute transmural myocardial infarction. Science, 120, 497.

Lewis, M. J. (1967). Serum CPK activity in the diagnosis of acute myocardial infarction. Pennsylvania Medicine, 70, No. 4, 77.

Maclean, D., Griffiths, P. D., and Emslie-Smith, D. (1968). Serum-enzymes in relation to electrocardiographic changes in accidental hypothermia. Lancet, 2, 1266.

Meltzer, H. (1968). Creatine kinase and aldolase in serum: abnormality common to acute psychoses. Science, 159, 1368.

Meltzer, H. Y., Mrozak, S., and Boyer, M. (1970). Effect of intramuscular injections on serum creatine phosphokinase activity. American fournal of the Medical Sciences, 259, 42.

Nissen, N. I., Ranløv, P., and Weis-Fogh, J. (1965). Evaluation of four different serum enzymes in the diagnosis of acute myocardial infarction. British Heart fournal, 27, 520.

Nygren, A. (1966). Serum creatine phosphokinase activity in chronic alcoholism, in connection with acute alcohol intoxication. Acta Medica Scandinavica, 179, 623 .

Pagliaro, L., and Notarbartolo, A. (1962). $\alpha$-hydroxybutyric dehydrogenase in the diagnosis of myocardial infarction. Lancet, $\mathbf{1}$, 1043. 
Preston, J. A., Batsakis, J. G., and Briere, R. O. (I964). Serum ' $\alpha$-hydroxybutyrate dehydrogenase'. A clinical and laboratory evaluation in patients with myocardial infarction. American fournal of Clinical Pathology, 41, 237.

Preston, J. A., Batsakis, J. G., Briere, R. O., and Taylor, R. V. (1965). Serum creatine phosphokinase. A clinical and laboratory evaluation. American Fournal of Clinical Pathology, 44, 7I.

Rinderknecht, H., Silverman, P., Haverback, B. J., and Geokas, M. C. (1970). Serum creatine phosphokinase in acute pancreatitis. Clinical Biochemistry, 3, 165 .

Rosalki, S. B. (1963). Serum $\alpha$-hydroxybutyrate dehydrogenase: a new test for myocardial infarction. British Heart fournal, 25, 795.

Rosalki, S. B., and Wilkinson, J. H. (1960). Reduction of $\alpha$-ketobutyrate by human serum. Nature (London), 188, I I IO.

Rosalki, S. B., and Wilkinson, J. H. (1964). Serum alpha-hydroxybutyrate dehydrogenase in diagnosis. Fournal of the American Medical Association, 189, 6r.

Savignano, T., Hanok, A., and Kuo, J. (1969). Creatine phosphokinase activity. A study of normal and abnormal levels. American fournal of Clinical Pathology, 51, 76.

Schiavone, D. J., and Kaldor, J. (1965). Creatine phosphokinase levels and cerebral disease. Medical Fournal of Australia, 2, 790.

Smith, A. F. (1964). Serum-enzymes in myocardial infarction. Lancet, 2, II 43.

Smith, A. F. (1967). Diagnostic value of serumcreatine-kinase in a coronary care unit. Lancet, 2, 178.

Sorensen, N. S. (1963). Creatine phosphokinase in the diagnosis of myocardial infarction. Acta Medica Scandinavica, 174, 725.

Stuart, J., Crawford, I. C., Forshall, J., and Owen,
J. A. (1965). Serum hydroxybutyrate dehydrogenase in myocardial infarction. British Medical Fournal, $1,423$.

Tammisto, T., and Airaksinen, M. (1966). Increase of creatine kinase activity in serum as sign of muscle injury caused by intermittently administered suxamethonium during halothane anaesthesia. British fournal of Anaesthesia, 38, 5 Io.

Velez-Garcia, E., Hardy, P., Dioso, M., and Perkoff, G. T. (I966). Cysteine-stimulated serum creatine phosphokinase: unexpected results. Fournal of Laboratory and Clinical Medicine, 68, 636.

Vincent, W. R., and Rapaport, E. (I965). Serum creatine phosphokinase in the diagnosis of acute myocardial infarction. American fournal of Cardiology, 15, 17 .

Warburton, F. G., Bernstein, A., and Wright, A. C. (I965). Serum creatine phosphokinase estimations in myocardial infarction. British Heart fournal, 27, 740.

Worthy, E., Whitehead, P., and Goldberg, D. M. (1970). Advantages and limitations of a simplified colorimetric assay for ATP : creatine phosphotransferase activity of human serum. Enzymologia Biologica et Clinica, II, 193.

Wroblewski, F. (1958). The clinical significance of alterations in transaminase activities of serum and other body fluids. In Advances in Clinical Chemistry, Vol. I, p. 313. Ed. by H. Sobotka and C. P. Stewart. Academic Press, New York and London.

Wroblewski, F. (1959). The clinical significance of transaminase activities of serum. American fournal of Medicine, 27, 911.

Requests for reprints to Dr. D. M. Goldberg, Department of Chemical Pathology, The Royal Hospital, West Street, Sheffield Sr 3SR. 